\title{
Rise and fall in ischemic heart disease mortality - it may have happened before
}

\author{
Maria Inês R. Azambuja \\ Departmento de Medicina Social, Faculdade de Medicina. Universidade Federal do \\ Rio Grande do Sul. Porto Alegre, RS - Brasil
}

\begin{abstract}
The rise in ischemic heart disease(IHD) mortality occurring mostly during the first half of the 20th century is usually associated with economic development and its consequences for people's lifestyles. On the basis of historical evidence, it is postulated that a previous IHD epidemic cycle may have occurred in England and Wales towards the turn of the nineteenth century. The implications of this on causal theories and current etiological research on atherosclerosis are discussed.
\end{abstract}

Myocardial ischemia, mortality

\section{Introduction}

A rise and fall in ischemic heart disease (IHD) mortality has occurred in the United States, as well as in several other countries, over the last 60 years. Three conferences ${ }^{2,3,5}$ were held between 1978 and 1988 to discuss the epidemic, without any significant progress being made towards the general understanding of its determinants.

The increasing impact of the IHD mortality upon the overall mortality rates was concomitant with the economic development of the industrialized countries, particularly following World War II. The rise in IHD mortality was naturally taken as a result of that development and of its consequences on people's lifestyles, associated with the demographic changes already in course since the turn of the century. The fact that researchers had all elected the descending limb of the cardiovascular mortality curve as the one which deserved to be explained is highly significant.

Etiological research on IHD followed in the wake of those conceptions, and of their associated paradigm: the lipid hypothesis ${ }^{1,4,6,10}$, one up-to-date version of it being that expressed by Ross ${ }^{8}$ :
Diet-induced hypercholesterolemia leads to
changes in endothelium and monocytes that
result in increased monocyte adherence,
subendothelial migration, accumulation of
lipid to form foam cells and gradual accumu-
lation of smooth muscle to form fatty streaks.

The lipid hypothesis as the dominant theory on atherogenesis and IHD causation, and changes in individual lifestyles as probable determinants of the observed secular changes in IHD mortality have logically oriented the choice of the main variables under study, either in individual-centered or in population-based research.

To demonstrate that all the research effort, time and money spent during the last 15-20 years did not bring the expected results, suffice it to say that the conclusions of the Decline Conference of 1978 remain valid to this date:

Although the decline in coronary heart dis. ease (in the US) is real, the probable cause or causes could not be precisely identified... both primary prevention through changes in risk factors, and fundamental and clinical research leading to better medical care, 
probably have contributed to but do not fully explain the decline".

Such poor progress towards the understanding of disease causation seems a sure indication that, somewhere, someone took the wrong turning.

\section{Reframlng the Problem}

Concomitance of economic development and rise in IHD mortality has been understood as causal association. Is it not possible that it might have been just a question of coincidence in time? If that was so, and if one regards the mortality trend as a true epidemic, it would be reasonable to ask if other epidemics might not have occurred in the past!

\section{Methodology}

A comprehensive review of the historical development of knowledge relating to coronary circulation and its diseases, written by Willius in 1945$46^{1-14}$ was found to be a valuable source of information in the search for an anwer to the above question. It gives an excellent account of the emergence of clinical descriptions of angina in the eighteenth century and of disputing views regarding its true nature during the nineteenth century, with physicians' opinions varying from symptoms of purely nervous origin to symptoms of an ischemic nature based on impaired coronary arteries.

Going through Willius's review with the hypothesis of an IHD epidemic in mind could lead to different interpretations of some of the original historical records quoted by him.

\section{Results}

During the early industrial revolution thousands of people moved from the land to crowded urban centers 9 . Disease and misery increased and became more obvious?. The growth of large towns made the development of very large hospitals possible ${ }^{y}$. Around 1760 , the majority of the large general hospitals in London had already been established'. Rather than continuing the medieval practice of providing for the poor, hospitals began to limit themselves to the care of the sick. This exerted a peculiar influence on the medical sciences, as it ensured a supply of clinical material adequate for the needs of systematic research".
According to Willius ${ }^{13}$, though earlier mention of the anginal syndrome had occurred, the most complete and classical description of it was that by Heberden(1710-1801) of London. Heberden apud Willius $^{13}$ (p.331-3) was not aware of the fact that the syndrome he masterfully described was associated with disease of the heart when, in 1772 , he named the disorder angina pectoris:

But there is a disorder of the breast marked with strong and peculiar symptoms, considerable for the kind of danger belonging to it, and not extremely rare, which deserves to be mentioned more at length. The seat of it and the sense of strangling and anxiety with which it is attended, may make it not improperly be called angina pectoris. Those who are afflicted with it, are seized while they are walking (more especially if it be uphill, and soon after eating) with a painful and most disagreeable sensation in the breast, which seems as if it would extinguish life if it were to increase or to continue; but the moment they stand still, all this uneasiness vanishes. In all other respects, the patients are, at the beginning of this disorder, perfectly well, and in particular have no shortness of breath, from which it is totally different. The pain is sometimes situated in the upper part, sometimes in the middle, sometimes in the bottom of the os stemi, and often more inclined to the left than to the right side. It likewise very frequently extends from the breast to the middle of the left arm. The pulse is, at least sometimes, not disturbed by this pain, as I have had opportunities of observing by feeling the pulse during the paroxism. Males are more liable to this disorder, especially such as have past their fiftieth year. After it has continued a year or more, it will not cease so instantaneously upon standing still; and it will come on not only when the persons are walking, but when they are lying down, especially if they lie on the left side and oblige them to rise out of their beds. In some inveterated cases it has been brought on by the motion of a horse, or a carriage, and even by swallowing, coughing, going to stool or speaking, or any disturbance of mind.

Such is the most usual appearance of this disease; but some varieties may be met with Some have been seized while they were 
standing still, or sitting, also upon first waking out of sleep; and the pain sometimes reaches to the right arm, as well as to the left and even down to the hands, but this is uncommon; in a very few instances tha arm has at the same time been numbed and swelled. In one or two persons the pain has lasted some hours or even days; but this happened when the complaint has been of long standing, and thoroughly rooted in the constitution; once only the very first attack continued the whole night.

I have seen nearly a hundred people under this disorder, of which number there have been three women and one boy twelve years old. All the rest were men near or past the fiftieth year of their age...

...The termination of the angina pectoris is remarkable. For if no accident interferes, but the disease goes on to its height, the patients all suddenly fall down, and perish almost immediately. Of which indeed their frequent faintness, and sensations as if all the powers of life were failing, afford no obscure intimation.

It is self-evident from Heberden's description that angina pectoris was by no means a rare condition at that time in London. In accordance with this is the fact that, before the end of the century, John Hunter(1728-1793), Eduard Jenner (17491823) and Calleb Parry(1755-1822) had firmly established the relationship of this clinical picture with hardening and narrowing of the coronary arteries, through postmortem examination in cases in which the patients had had angina ${ }^{13}$. By the end of the eighteenth century, angina pectoris was a well established clinical entity. As was stated by Parry apud Willius ${ }^{13}$ (p. 334), in 1799:

\section{Although there can be no reason to doubt that mankind must have been subjected to this disorder from the remotest antiquity, it is somewhat extraordinary that so many ages have elapsed without any notice of its existence either as a distinct disease, or as a variety of one commonly known.}

His surprised reference to the novelty of the emergency of angina is remarkable.

In 1909, Burns(1781-1813) apud Willius ${ }^{14}$ (p.78) accepted the coronary origin of the angina as indicated by the following quotation:
To Drs. Heberden, Jenner and Parry we owe the most of our information respecting this most fatal complaint... (which the latter) has incontrovertibly proved to originate from some organic laesion of the nutrient vessels of the heart.

Burns was the pioneer sponsor of the ischemic theory of angina pectoris (In Willius:

But how to explain, after the exceedingly good characterization of the angina pectoris and its incontrovertibly proved association with obliterative disease of the coronary arteries (which had taken place in the late 1800's), the prevailing confusion regarding its true nature towards the second half of the nineteenth century? Forbes, apud Willius ${ }^{14}$ (p.81), in England, claimed in 1845 :

In about 50 per cent of cases of angina there were no organic disease and in the remaining cases, a great variety of cardiac and especially aortic lesions occurred.

Gibson, apud Willius's (p.81), in Edinburgh, stated in 1898 :

The group of symptoms known from the date of their earliest scientific analysis by the term angina pectoris, forms a variable picture produced by morbid conditions scarcely if at all less diverse in character than the clinical appearances.

It was as if within a period of about 70 years (1772-1845), the angina pectoris had lost its original strength as a distinctive clinical entity. Its historically associated symptoms seemed to have become more diverse in character and less specifically related to disease of the coronary arteries then they once had been.

Considering chest pain a diagnostic test for an anatomo-pathological diagnosis of obliterative disease of the coronary arteries, according to modern epidemiological concepts, a temporal reduction of the predictive value of chest pain relating to disease of the coronary arteries could be explained $b y$, a reduction of the prevalence of this disease over time.

Based on such compelling historical and epidemiological evidences, one is obliged by reason to recognize that a previous IHD epidemic may have occurred towards the turn of the nineteenth century, in England and Wales. 


\section{Discussion and Conclusions}

The recognition of a previous epidemic cycle of IHD (particularly one occurring in possibly the most depressed years of that population) would immediately disqualify individual lifestyles as a possible determinant of temporal trends in IHD mortality. It would equally weaken the lipid hypothesis as the main explanatory theory for atherogeneses. Both hypotheses are inconsistent with a previous IHD epidemic assumption.

Diet-induced hypercholesterolemia (and possibly other "risk factors") would still retain a contributory role within the causal web leading to IHD mortality. But the time may have come when etiological research should put aside the continuing search for the causes of individual cases to search instead for the cause of the epidemic presentation of the disease.

\section{References}

1. CONSENSLS Conference: lowering blood cholesterol to prevent coronary heart disease. JAMA, 253: 2080-90, 1985.

2. HIGGINS, M.W. \& LLJEPKER, R.V. ed. Thends in coronary beat disease montalit: the influence of medical care. Ner. York. Oxford University Press, 1988.

3. HIGGINS, M.W. \& LLEPKER, R.V. ed. Trends and determinants of coronary heart disease mortality: international comparisons. Int. 7 . Epidemiol, 18: S1-S32. 1989.

4. KEYS, A. Coronary heart disease in seven countries. Circulation. 41(suppl, 1): I211. 1970.

5. NATIONAL INSTITLTE OF HEALTH. Proceedings of the conference on the decline in coronary beant disease mortality. Washington, D.C. L'S Government Printing Office. 1979. (LS Department of Health, Education and Welfare: NIH publication 79-1610).

6. PARRY, C.H. apud WILLIES, F.A. The historic development of knowledge related to coronary circulation and its diseases: the eighteenth century Staff Meet Mayo Chnic, (Sep): $331-3,1945$.

7. ROSEN, G. A bistory of public bealth. New York, MD Publications Inc, 1958.
8. ROSS, R. The pathogenesis of atherosclerosis - an update. N. Engl. J. . Ked. 314: 488-500, 1986.

9. SHRYOCK. R.H. The development of modern medicine: an interpretation of the social and scientific factors intolled. Madison. The Lniversity of Wisconsin Press, 1979.

10. STAMLER, J.; WENTWORTH, D.; NEATON, J. Is the relationship between serum cholesterol and risk of death from $\mathrm{CHD}$ continuous or graded? IAMA. 256: 2823-8, 1986.

11. WLLILS, F.A. The historic development of knowledge related to the coronary circulation and its diseases: introduction and the preharteian era. Proc. Staff Heet. Mayo Clinic. 20: $103-6,1945$.

12. WILLILS. F.A. The historic development of knowledge related to the coronary circulation and its diseases. II. Harvey and the seventheenth century. Proc. Staff Meet. Mayo Clinic, 20:155-6, 1945.

13. WLLILS. F.A. The historic development of knowledge related to the coronary circulation and its diseases: the eighteenth century. Proc. Staff . Heet Mayo Clinic, 20: 326-36, 1945

14. WILLIUS, F.A. The historic development of knowledge related to the coronary circulation and its diseases. The ninetheenth century. Proc. Staff Meet Majo Clintic. 21: 77-90. 1946.

\section{Resumo}

O aumento na mortalidade por cardiopatia isquêmica ocorrido neste século é usualmente associado ao desenvolvimento económico e a suas conseqüencias no estilo de vida das pessoas. Com base em evidencias históricas, levanta-se a possibilidade de ter havido outro ciclo epidêmico de cardiopatia ao redor da virada para o século 19, na inglaterra, e discute-se as implicaçöes decorrentes desta hipótese para a pesquisa em aterogenese.

Isquemia miocárdica, mortalidade. 